\title{
The Shadow and the Substance of Lenin after 150 Years
}

\author{
A. MARSHALL*
}

\begin{abstract}
*Alex Marshall - DSc in History, Senior Lecturer, University of Glasgow. Address: History, Room 406, 1 University Gardens, Glasgow G12 8QQ, United Kingdom. E-mail: Alexander.Marshall@glasgow.ac.uk
\end{abstract}

Citation: Marshall A. (2020) The Shadow and the Substance of Lenin after 150 Years. Mir Rossii, vol. 29, no 4, pp. 134-149. DOI: 10.17323/1811-038X-2020-29-4-134-149

150 years since Lenin's birth marks an anniversary that raises questions around Lenin's meaning today and his ultimate historical legacy. By distinguishing both Lenin the man, and the cult of commemoration that for 60 years surrounded him, from the core method behind Lenin's own thought, this article addresses the question of if and why Lenin still matters in Europe today. It does so by arguing for an Ilyenkovian reading of Lenin's main ideas and contributions. The current condition of European politics is, to a significant degree, still a by-product of the rejection of 'Leninism' after 1989, Leninism having evolved after 1924 into a sociological construct designed predominantly to facilitate the accelerated industrialization of backward societies. The rejection of Leninism as an alternate form of modernity led, via a consciously post-modern moment in central and eastern Europe, to the substitution of 'memory politics', fostering a more openly competitive political culture focused around race, identity, religious faith, and often radical ethnic nationalism. The dangers of such an outcome were foreshadowed in the concerns of the Soviet philosopher Evald Ilyenkov, who sought in the 1960s and 1970s to counterbalance the rise of neopositivist thinking in his era by revisiting the dialectics of the ideal first explored by Marx and Lenin. Whilst Ilyenkov saw mechanistic materialism as the greater latent danger in his own day, he also opposed the subjective idealism of 'socialism with a human face', and the idealist currents that arose in response to neopositivist rhetoric in Soviet social life. He found in Lenin an intellectual ally of his own belief that the true definition of the ideal emerges via the collaborative collective activity of society as a whole in a particular historical moment, rather than via embracing one or other of these two extremes. Through Ilyenkov, Lenin continues to speak to our own times.

Key words: V.I. Lenin, E.V. Ilyenkov, Leninism, postmodernism, dialectics, materialism, philosophy, Europe 
Noting that 150 years have passed since Vladimir Ilyich Lenin's birth is in some regards simply to cite a number, although in many circles it is also typically taken to constitute a 'significant anniversary', an occasion to revisit someone's life and legacy. In order to attempt the latter, and to discuss the significance of the $150^{\text {th }}$ anniversary of Lenin's birth, it is, however, perhaps useful to begin by considering some other kinds of numbers first. In 1991, Ukraine had 5,500 Lenin monuments of various kinds. Today, in 2020, there are only two Lenin statues left, both located in the Chernobyl nuclear exclusion zone. The removal, over the course of 30 years, of all of these statues and other monuments occurred in waves, much of it government directed and sanctioned, with the fastest wave of deliberate de-memorialization occurring after 2013 [Raining Lenins 2020]. This rampage of the state sanctioned destruction of monuments obviously predated the more recent shift in Western countries to reconsider and remove memorials now associated with what are today considered morally reprehensible historical phenomena, be they the Trans-Atlantic slave trade, or the Southern Confederacy in the US. The earlier wave of destruction of Lenin memorials also involved remarkably little in the way of deliberate relocation or reorientation. In Ukraine at least, these statutes and other memorials were not relocated to museums, where they could be recontextualized and discussed, but were simply first defaced and then physically obliterated.

Why is this phenomenon worth mentioning on the $150^{\text {th }}$ anniversary of Lenin's birth? Precisely because it underlines that any discussion of Lenin and his historical significance and legacy long ago ceased to be simple or easy. When dealing with and discussing Lenin today, any researcher or analyst has to deal with the Hegelian phenomena of the 'three Lenins'. In order to discuss any notion of Lenin's enduring significance or meaning in an anniversary setting, one has to therefore first clarify which Lenin one is discussing. In this article I shall attempt to do so, studying and recording, but also parsing away, both the 'father and son' to then discuss the 'spirit' or 'Holy Ghost' of Lenin in the $21^{\text {st }}$ century. In attempting to arrive at this 'spirit', I will advocate an Ilyenkovian reading of Lenin (the Soviet philosopher Evald Ilyenkov) in order to determine both what most distinguishes Lenin's philosophical thought from that of our own times, and why I would argue that such a core, or 'spririt', remains an essential reference point even today. To preface this eventual conclusion, I argue that what remains ultimately relevant about Lenin is his insistence on the concept of the ideal in human history. This is a deeply unfashionable concept in the current post-modern world of 'memory politics'. Without it however, politics itself arguably loses its meaning, and the ideal consequently represents a concept to which human civilization itself needs to, at some stage, return. Such a conclusion does not pretend to define the ideal itself as somehow an uncontested or in any way fully resolved subject-modern politics itself traditionally arose from contested notions of the ideal-but it seeks to underline the fact that the ideal itself has been lost as a referent object in the majority of advanced societies, in favor of pure plurality. Any call to return to a world defined by the ideal, however, obviously also requires a conscious accounting of how the very notion of the ideal was itself warped and misinterpreted in the twentieth century, and a consideration of how and why a certain liberal vision of the ideal is now also being increasingly rejected by a growing number of societies in the $21^{\text {st }}$ century [Kravtsev, Holmes 2020].

This article therefore begins by summarizing and parsing away, as a preliminary exercise, both the 'empirical' Lenin, embodied by his vast physical legacy of books, pamphlets and speeches on hundreds of topics, still well preserved today in multiple 
editions, and the 'mythological' Lenin of 'Leninism', whose reification formed so much of the institutional glue that held the Soviet Union together for the majority of its existence. If one were to argue for the overriding relevance of the 'first' Lenin, then he is 'merely' a major historical actor, the equivalent to a Lincoln, Roosevelt or Churchill, of critical importance to the understanding of his own era, but not necessarily of longer-term significance. If one were, on the other hand, to privilege 'Leninism' as Lenin's own chief legacy, this would be to acknowledge Lenin's essential irrelevance today, on the $150^{\text {th }}$ anniversary of his birth, given the demise of the main project associated with 'Leninism', the Soviet Union itself. If by contrast we wish to argue that there remains something of eternal relevance in Lenin's thought, a 'rational kernel within the mystical shell' [Marx 1873 (1954), p. 20] on this, the anniversary of his birth, we have to first disaggregate those aspects and legacies which are unquestionably also important, but which are nonetheless not going to contribute to important debates another 150 years from now.

With regard to the 'empirical' Lenin, or as Hegel might put it, the 'thing itself'; the man and his writings, the textual base remains by which to study and explain Lenin's own worldview and opinions, and which, for historians, will always continue to attract attention and study. Although there are many other avenues where one could begin to consider Lenin's thought and legacy, the 54 volumes of Lenin's Collected Works, which (often unread) formerly used to occupy pride of place in countless Soviet offices and living rooms, remains a key starting point for many, and for historians this legacy will also remain permanently relevant. This physical legacy is above all important for stressing the manner in which Lenin's own thinking evolved over time, for identifying the 'wrong turns' that he clearly made in his own lifetime, and to serve as a reminder that he was a human being and not a demigod; one just as prone to doubt, rage, self-delusion, and unbalanced reactions as the rest of us. Our consideration of Lenin's actual method of thought, to which I return later, acquires all the greater significance precisely because it forms a separate category for analysis compared to Lenin's own historically specific flaws, biases, strengths and weaknesses.

There is however also a second, and at one distinct stage removed, 'Lenin', namely the first major popularization of Lenin's own thought, 'Leninism'. This was the ideological canon created after Lenin's death, and used as a continuous rhetorical reference point first within the Soviet Union, and then later in the Eastern Bloc as a whole, for instrumental political purposes. 'Leninism' after 1924 was employed both to embalm Lenin himself, and to provide the intellectual justification for every subsequent twist and turn of Soviet domestic and foreign policy by party leaders in their day [Yurchak 2015; Yurchak 2017]. Critically, the creation of this canon also involved, and in fact depended upon, the manipulation, selective quotation, and even censorship of Lenin himself. Lenin's 'Testament' from 1923 was not published inside the Soviet Union until 1956, and an array of his other writings and policy interventions made during his own lifetime remained censored and unpublished until after the Soviet collapse [Lenin 1999]. This 'Leninism', as a canon of writings and ideas owned, popularized and manipulated by the party, was, therefore, from the outset very deliberately different from the Lenin known to his closest and most intimate contemporaries.

On top of its deliberate selectivity towards Lenin's actual thought and writings, 'Leninism' for the majority of its existence also proved a remarkably malleable state doctrine, invoked alternatively to justify agricultural collectivization under Stalin, De-Stalinization under Khrushchev, 'mature socialism' under Brezhnev, or 'glasnost 
and perestroika' under Gorbachev. Its core principle in the public consciousness for the majority of the Soviet Union's existence nonetheless remained remarkably consistent over time. I would argue that 'Leninism', as popularly understood, represented an alternate form of rapid modernization for a backward society, whose final destination was the condition defined as 'communism'. In this sense, despite outward changes in form and emphasis, the central content of official, state sponsored 'Leninism', as late as 1987, remained remarkably similar, in many respects, to the definition first given by Stalin in 1924 of the 'Leninist' formula of revolutionary modernization:

Leninism is a school of theory and practice which trains a special type of Party and state worker, creates a special Leninist style in work. What are the characteristic features of this style? What are its peculiarities? It has two specific features:

a) Russian revolutionary sweep and

b) American efficiency.

The style of Leninism consists in combining these two specific features in Party and state work [...]. American efficiency is that indomitable force which neither knows nor recognizes obstacles; which with its business-like perseverance brushes aside all obstacles; which continues at a task once started until it is finished, even if it is a minor task; and without which serious constructive work is inconceivable [Stalin 1924].

The Soviet Union, as the site of an alternate and utopian 'Second America', wherein the highest achievements of technology, resource exploitation, and modern industrial management techniques would be combined with levels of social justice unattainable in capitalist America itself, collapsed in 1991. The reasons for that collapse were multiple, they have been extensively studied, and they need no lengthy reiteration here. In essence though, the crisis and collapse of the Soviet system came about through a combination of economic stagnation, political anarchy, and moral bankruptcy. All three phenomena dealt massive blows to the official structure of 'Leninism'. The revival (and deepening) by Gorbachev of De-Stalinization, first initiated by Khrushchev back in 1956, led to a general lightening of censorship after 1985, and to further historical and archaeological revelations. These served to deliver a final and (as it turned out) fatal blow to Leninism's claims to moral superiority over capitalism in the public consciousness [Shane 1995]. The economic impulse of perestroika itself, initially intended to trigger a 'quickening' (uskorenie) of the economy, with a final breakthrough to technological modernity, ended instead in chaos and financial insolvency, the results of which first became glaringly apparent in 1989, in the effective abandonment of the Soviet sphere of influence in Eastern Europe [Miller 2016]. As these two trends played out, Gorbachev domestically also undermined the traditional role of the party, pursuing reforms after September 1988 that effectively sought to resolve the long-standing tension in partystate relations by increasingly privileging state institutions whilst also attempting to decentralize power to the regions [Gleason 1990]. The consequence of the effective sidelining of the CPSU, as the ultimate social network binding the union together, was a constitutional crisis triggered by rising nationalism within the state institutions of multiple union republics, and the dissolution of the union itself in December 1991. In the space of approximately six years, Leninism was effectively and comprehensively 
destroyed by those who, at least initially, apparently sought most ardently to reform and maintain it [Walker 1993].

The fall of Lenin statues across Eastern Europe and many ex-Soviet states is, in this sense, the last and most obvious consequence of this increasingly socialized rejection of Leninism. The act of removal and eradication itself symbolizes an open rejection of the forms of modernity that Leninism ultimately produced, and the vision it was felt to embody - an articulation of the view, which became increasingly vocally expressed after 1989, that Leninism itself had proven a historical 'dead end' [Popov 2010; Brown 2004]. It also very obviously represented an open contestation over public space and memory, in terms of past heroes and villains, and the triumph of a more ostensibly liberal and pluralistic view of history, via local 'memory politics'. As Dmitri Nikulin notes, when Enlightenment thinking underwent an increasingly general critique during the course of the late twentieth century, 'memory replaced this dethroned conception of reason by becoming the predominant capacity to which one refers when one wants to explain a historical, political or social phenomenon [....] Memory thus becomes the vehicle for collective self-understanding, often prompted by a collectively shared trauma, which becomes the basis for producing a new history' [Nikulin 2015, p. 5]. For many, the passing of a rigid 'ideology' was now naturally replaced by a highly competitive 'memory politics', welcomed in many circles as a natural additional ingredient in the generation of the open society advocated by Western advisors for post-communist societies [Popper 1945 (2011)].

This Western discourse alternative to Leninism itself evolved from Karl Popper's famous condemnation of 'teleological historicism' as the root philosophical source of all totalitarianism. Popper famously traced this philosophical current back through Marx and Hegel to, ultimately, Plato. If free markets were now seen as the only way to overall human prosperity, a free competition of ideas and symbols was now also deliberately encouraged to generate 'post-modern' politics, within which, it was hoped, anti-free market ideologies would never again be able to find sufficiently plausible purchase to become entrenched. All larger meta-narratives to explain human life as the working through of a certain form of reason were to be discarded. Yesterday's villain could now be plausibly reinvented and commodified as today's hero and martyr, and yesterday's hero could just as simply be recast as a villain; all opinions were now equal, and all enjoyed an equal and natural right to be heard, as mere commodities in a free marketplace of ideas. The near-universal fall of Lenin monuments since 1991 was accompanied by the raising of statues and memorials to the terrorist Stepan Bandera in Ukraine, to Estonians who served in the Waffen SS during the Second World War in Estonia, and to the White Supreme Leader Admiral Kolchak in Russia. In Russia itself in fact, following the collapse of the Soviet Union, more than 25 monuments have now also been raised to the memory of Tsar Nicholas II [Masis 2017]. The very diversity of these phenomena is itself often upheld as a victory for the open society, even whilst many of the past figures currently being commemorated were ironically themselves merely supporters of alternate varieties of totalitarian thought in their own day.

There is a further dual symbolic purpose in these acts of de-memorialization and revalorization. The first purpose, epitomized by the public defacement and often violent destruction of the Lenin monuments themselves, is a conscious desire both to shock, and to declare other versions of the past at least the equal, or even better, than the previous official account of history. The performative act itself is just as important as the content, 
given that it is often held to represent liberation from a now socially discredited version of the past. In this context, private acts of defacement often involved deliberate acts of subversion and humor, as well as more obvious threats and insults. There was also often a discernible and quite easily mapped political geography in relation to exactly how far public memory remained a contested subject; in Western Ukraine, which only became a part of the Soviet Union in 1939, all monuments to Lenin had already been removed as early as the autumn of 1991 [Gamboni 2013, p. 66]. The second purpose of actual memorial destruction and removal however was to construct new modes of public and collective memory, new sources of symbolic capital, and to redefine national identity. In Tashkent, the capital of Uzbekistan, the bust of Marx that once sat at the center of the city was famously replaced after independence by a statue of Tamerlane, the indigenous $14^{\text {th }}$ century Uzbek warlord [Zarkar 2015]. In Russia, President Boris Yeltsin, who as a Soviet official had earlier presided over the physical destruction of the historic Ipatiev house where the Romanov family were killed, led efforts during 1998 to return the Romanov family remains to St. Petersburg, and in the process to grant them a formal Russian Orthodox burial. Tellingly, Yeltsin's 1998 initiative came two years after he had also announced a yearlong competition to produce a new Russian 'national idea', a competition which famously ended, despite considerable financial incentives, without a winner or an answer [Forest, Johnson 2002, p. 530].

Important as these symbolic public acts are to tracing and mapping the remarkable overthrow of Leninism as a governing state idea after 1991, they have less to tell us about the core of Lenin's own thinking and beliefs. They arguably remain the equivalent of the shadows projected onto the wall in Plato's allegory of the cave; if one were to study Lenin's potential relevance only through the prism of the rise and fall of Leninism as a symbolic public imaginary, one would stand in danger of repeating the world view of the prisoners in that famous cave, mistaking the flickering shadows on the wall for the reality outside the cave. Although Leninism superficially embodied the physical realization of Lenin's ideas and beliefs for much of the $20^{\text {th }}$ century, and although these shadows were artfully manipulated by several members of the cave collective during that time, the phenomena of Leninism and its passing has much less to tell us about Lenin's own thinking, and about the rational core of the Leninist ideal, which still matters today. Leninism was unquestionably the prevailing and dominant social manifestation of those who declared themselves followers of Lenin in the $20^{\text {th }}$ century. It was certainly not, however, identical with the philosophical essence of Lenin's actual thought. The vanishing of certain shadows on the cave wall consequently does not mean that the inhabitants of the cave have also finally freed themselves, and now wander naturally at liberty beyond the confines of the cave itself.

The first Marxist philosopher in the Soviet Union who, while Leninism still existed, attempted to point out the growing gap between Leninism as it had come to be popularly and publicly interpreted, and the core philosophical content of Lenin's own ideas and thought, was the tragic figure of Evald Ilyenkov (1924-1979). Ilyenkov's philosophical output in the 1950s and 1960s was heavily shaped by the Khrushchevite thaw of De-Stalinization. His growing conflicts with the leaders of the official academic school of Diamat (Dialectical Materialism) during that time led him to be increasingly ostracized and marginalized within the Soviet academic establishment, a condition which undoubtedly contributed to his taking his own life in 1979. A recurring note in Ilyenkov's own thinking and writing was an attempted return to Lenin-a consistent 
effort to excavate the core philosophical principles that had guided Lenin himself during his own lifetime, separate from the scaffolding and architecture of Leninism that had been erected after Lenin's death. This was in itself a response to the neopositivism which Ilyenkov felt increasingly characterized official Diamat in his own day.

During Ilyenkov's lifetime, the official definition of communism - the 'ideal' in Soviet thought-was expressed in increasingly concrete, positivist, and specific material terms. This flowed naturally from the Stalinist interpretation of Leninism as American-style modernization with a Russian (revolutionary) twist and found perhaps its final and highest public expression in the (in)famously utopian materialism of the 1961 communist party program [Titov 2009]. This program notoriously proclaimed that by 1981, the 'material and technical base' of communism would be largely achieved, and it set in stone specific concrete tasks for each decade, milestones which the Soviet Union then infamously failed to meet. Such tasks included the goal that, by 1970, 'hard physical work will disappear', that by that stage the USSR would also have the shortest working day in the world, while by 1980 the abundance of goods would be such that their distribution could begin to occur on the basis of needs. Shops and factories would become increasingly automated, the real income per head of the population was forecast to grow by 250 percent in 20 years, housing was to become rent-free, public catering would replace domestic cooking within 10-15 years, public transport would be free by the end of the second decade, and the housing problem itself would be generally resolved [The Program of the Communist Party of the Soviet Union 1961]. The 1961 program represented the high tide of a concrete, highly empirical vision of what communism would mean, with individual production targets in almost every imaginable material category being generated. As before, the final basic measure of comparison here, by which communism was to be judged to have been finally accomplished, remained the US, which the Soviet Union, in Khrushchev's famous catchphrase, was destined to 'catch up [with] and overtake'. This highly concrete and specific vision was not coincidentally followed by widespread disillusion and disengagement, as everyday reality failed to meet the often abstract targets set by the program. Disillusionment was bred not only by the obvious failure to 'catch up and overtake' the US, but by the catastrophic environmental damage inflicted as a consequence of the developmental ideology itself. In the 25 years which followed the publication of the program, the Aral Sea in Central Asia became a desert, the Chernobyl disaster permanently contaminated significant areas of Ukraine and Belarus with nuclear fallout, and widespread air and water pollution became endemic in many cities across Russia, from Moscow to Vladivostok, vastly increasing the rate of both birth defects and premature deaths [Peterson 2019].

The vision of communism espoused in the 1961 program, however, reflected one of the central tenets of official Diamat; the binary distinction between matter and consciousness. In official Diamat, matter itself formed the superstructure that shaped reality; consciousness was only a response, an individualized subjective neurological registration of an externally objective reality. Reducing the conceptualization of the ideal (in this case, 'communism') to a chemical response in the brain produced by external stimuli transformed the brain itself into a 'programmable' organ, for which the prime prerequisite naturally became these external material conditions. This increasingly strong strain of scientism led one interviewer, decades later, to ask Sergei Mareev (1941-2019), a student of Ilyenkov's and a major philosopher in his own right, whether the 'secret' ideology of the Soviet Union had not in fact become scientism rather than 
Marxism-Leninism. Mareev responded that positivism did probably verge on becoming the 'official world view' of the late Soviet epoch, something that had provoked growing anti-scientism amongst Ilyenkov's humanistically-minded philosophical colleagues, though he opined that the positivist trend at the time was stronger in Diamat than Istmat (historical materialism), given that the latter certainly recognized that consciousness had a social character. For Ilyenkov himself, Mareev also speculated that this split between scientism and anti-scientific world views represented a false opposition; what in Ilyenkov's view was critical was not the new science of cybernetics itself for example, but the over-reliance on this as:

the ideal and as the means for solving all problems. It is precisely from this that positivism and scientism grows. But at the other extreme, where solutions to all problems are sought in religion, morality and moralism, and most commonly, pure verbiage - these were not for Ilyenkov. He was certainly far from this kind of 'humanism ' [...] he was not pleased by all the talk about 'humanism', 'socialism with a human face', and so on because he knew well what would follow. And what followed is what we have now-the same bureaucracy but without a human face [Levant, Oittinen 2014, pp. 91-94].

For our present purposes, what is significant about Ilyenkov's contribution, given the general philosophical trends in his own lifetime, is his attempt to recover a more creative form of thinking and a conceptualization of the ideal via a return to Lenin. In this endeavor, Ilyenkov found a useful historical parallel for his own time which he underlined in his last book, the posthumously published Leninist Dialectics and the Metaphysics of Positivism. The historical parallel here was the debate that had exploded after 1908 between Lenin and another leading thinker in the Bolshevik party at the time, Alexander Bogdanov. Bogdanov's vision of socialism had just been outlined in populist style in his 1908 science fiction novel Red Star, which used the then-fashionable parable of life on Mars to investigate the future nature of scientific socialism.

On Mars, the literal 'Red Planet' of the novel, Martian life by 1905, the year of the novel's setting, had been re-ordered by the latest scientific discoveries to remove all sources of conflict and distress. The state had disappeared, as had private property, labor had been reduced to a few hours a day through the wonders of automation, and the distress of death itself had been traduced by freely available voluntary euthanasia. Society had entered a state of complete equilibrium, which the novel portrays as the natural outcome of socialism's accomplishments. The only problem that remained was the growing exhaustion of Mars's own natural resources, which appeared to require a Martian invasion of Earth, colonization, and the extermination of the still unfortunately far less advanced human race [Ilyenkov 1982, pp. 58-66]. This tragic outcome is avoided in the novel by the intervention of love between a Martian and an Earthman, which results in the invasion being delayed in order to give more time for the coming social revolution on Earth to occur. Ilyenkov is particularly scathing of two aspects of the novel that he clearly read as characteristic of the emerging positivist trends and of the visions of the ideal in general in his own day. The first is the assumption made in the novel that socialism equates to equilibrium - that advanced socialism produces a society, as on Mars, without internal conflicts or contradictions of any kind, where production is simply and efficiently 
conducted and encoded using 'gigantic calculating machines' [Ilyenkov 1982, p. 59]. The second is Bogdanov's need to insert love into the novel, as the counterbalance that eventually somehow saves humanity. As Ilyenkov ironized of this plot device:

\begin{abstract}
When fetishized science and scientific thinking lead to immoral conclusions [...] then the scientist sheds a tear, and begins to seek salvation in abstract and empty, but 'humane' ideals, placating his romantic but, alas, absolutely barren nobility [Ilyenkov 1982, p. 66].
\end{abstract}

Ilyenkov's criticism of Bogdanov's thought here clearly reflected his own opposition to what he saw as the two emerging trends in philosophy. It is fair to surmise that he saw in Bogdanov the embodiment of the two recurring philosophical extremes of subjective idealism, extremes which portrayed the ideal either in rigid official Diamat terms of purely material technocratic modernization, or in its natural opposite-subjective and abstract humanistic mysticism, love, morality, or religion. This particular opposition was reflected in the novel's own stark portrayal of the differences between life on Mars and life on Earth, with a rigid teleological arc of development between the two societies, and love, or emotion, portrayed as the only short-term mediating force. Given these parallels, it is also no coincidence that Ilyenkov saw in Lenin, Bogdanov's philosophical and political opponent at the time, a possible intellectual rescue and route out of what Ilyenkov himself perceived as this increasingly threatening intellectual dead end.

Bogdanov's views and writings famously stirred in Lenin a furious polemical response, the 1908 text Materialism and Empirio-Criticism, but also triggered in him a longer-term interest in the roots of dialectics in philosophy in general, which led Lenin, during the First World War, to re-acquaint himself with the Ancient Greek philosopher Heraclitus, with Aristotle's Metaphysics, and finally with Hegel's Science of Logic. In his last written work, Ilyenkov sought both to rescue Lenin's 1908 work and to underline the philosophical continuity of Lenin's development after that date, noting that

the content and significance of this highly polemical work is interpreted too narrowly and one-sidedly, and consequently incorrectly. And not only by open enemies of revolutionary Marxism, but also by some of its 'friends' [Ilyenkov 1982, p. 3].

For Ilyenkov, Lenin was a key ally in Ilyenkov's understanding of the ideal, which was dialectical. The 'ideal' was neither a chemical and purely individual reaction in the human brain to external stimuli, nor was it the product of abstracting entirely from external reality to an individual and subjective emotional or spiritual position on some separate plane (the role now increasingly assigned to 'memory'). It was, rather, a product of social activity, and more than that, of society as a whole in a particular historical epoch:

The real materialist solution to the problem in its present formulation [...] was found as we know by Marx, who 'had in mind' an entirely real process, specifically inherent to human life activity: the process by which the material life activity of social man begins 
to produce not only a material but also an ideal product, begins to produce the act of idealization of reality [...] and then, having arisen, the 'ideal'becomes a critical component of the material life-activity of social man, and then begins the opposite process-the process of the materialization (objectification, reification, 'incarnation') of the ideal.

These two actually opposite processes eventually lock into more or less pronounced cycles, and the end of one process becomes the beginning of the other, opposite one, which leads in the end to the motion of a spiral shape, with all its ensuring dialectical consequences (Ilyenkov "Dialectics of the Ideal" in [Levant, Oittinen 2014, p. 36]).

Lenin's own articulation of this method of thinking reached perhaps its most condensed form in his wartime Philosophical Notebooks but was, Ilyenkov argued, a natural extension and further development of his initial engagement with Bogdanov in 1908 over the nature of physical reality. Lenin drew from Heraclitus that human history was not a teleological arc, leading from emotional chaos and inequality to a Martian system of perfect equilibrium without contradictions, but in the true dialectical materialist worldview was a constant conflict of continuously emerging and submerging contradictions. The same distinction led Lenin to debate fiercely with Bukharin and Kautsky when both men, in his eyes, seemed to propose, at different times, and in their own ways, the existence of a frictionless route to socialism. As Heraclitus himself had put it, in what Lenin at the time praised as 'a very good exposition of the principles of dialectical materialism':

The world, an entity out of everything, was created by none of the gods or men, but was, is, and will be eternally living fire, regularly becoming ignited and regularly becoming extinguished [Lenin 1972, pp. 344, 347].

Such a perception led Lenin naturally to embrace the need for revolution in Russia in 1917 as a necessary social act, a logical step in an ongoing process. Although he was a supporter as early as 1918 of the importation of American-style management techniques, specifically Taylorism, as a means to assist Russia through the catastrophic economic collapse created by war and the revolution itself, Lenin's final writings on the nature of the Soviet state were also much more modest, without any of the rhetoric around catching up and surpassing America that later became one of the central tenets of 'Leninism'. Lenin's last writings spoke instead to the importance of now cultivating an authentically new and different human culture:

If a definite level of culture is required for the building of socialism (although nobody can say just what that definite 'level of culture' is, for it differs in every Western European country), why cannot we began by first achieving the prerequisites for that definite level of culture in a revolutionary way, and then, with the aid of the workers' and peasants'government and Soviet system, proceed to overtake the other nations?

You say that civilization is necessary for the building of socialism. Very good. But why could we not first create such prerequisites of civilization in our country by the expulsion of the 
landowners and the Russian capitalists, and then start moving toward socialism? Where, in what books, have you read that such variations of the customary historical sequence of events are impermissible or impossible?

Napoleon, I think, wrote: 'On s'engage et puis ... on voit.' Rendered freely this means: 'First engage in a serious battle and then see what happens.' Well, we did first engage in a serious battle in October 1917, and then saw such details of development (from the standpoint of world history they were certainly details) as the Brest peace, the New Economic Policy, and so forth. And now there can be no doubt that in the main we have been victorious [Lenin 1965, pp. 478-480].

Lenin's definition here of the politics of the ideal as, above all, a collective social activity, rather than an abstract exercise in personal mental enlightenment, undoubtedly terrifies many today, in the wake of a century of grand social experiments that produced hecatombs of intended and unintended dead in their wake. The rejection of political metanarratives, and the rise of a highly individualized and decentralized 'memory politics' as the preferred alternative of social organization in most advanced modern societies is undoubtedly the conjoined product of both the social trauma of such earlier collective experiences and their conscious intellectual rejection by figures like Karl Popper-the biases of which continue to pervade analytic philosophy in Western academia today. The 'research project' that Lenin foresaw in his Philosophical Notebooks, however, envisioned avenues of investigation which went beyond mere killing fields of terror and destruction. They included developing 'fields of knowledge from which the theory of knowledge and dialectics should be built', including psychology, the study of language, the history of cognition in general, and the mental development of the child [Lenin 1972, p. 351]. Lenin never lived to see this program implemented, but during the Soviet era various activists within Soviet academic life, including Lev Vygotsky and Ilyenkov himself, undertook substantial practical work in these directions. Such avenues of activity were symbolized, for example, by Ilyenkov's work with the disabled (blind-deaf children), which in the 1970s saw some of the most socially disadvantaged in society for the first time enter and successfully graduate from Moscow State University.

Ilyenkov's predominant intellectual concern was what he perceived as the rising tide of positivism, and a related crude materialism which was being increasingly used to define both socialism and the ultimate state of communism. He would perhaps be surprised, had he lived longer, to witness, paraphrasing Lenin, how far the stick has now been 'bent back the other way.' In June 2020, for example, Hungarian Prime Minister Viktor Orban proposed a new and entirely subjective idealist metric for Hungarian history - the Trianon (a reference to the 1920 Treaty of Trianon). Hungarian history in this narrative had enjoyed four hundred years of independence (four Trianons), followed by a calvary of humiliation and suffering, before renewed independence, which led to the present moment, when the modern Hungarian continues to see the world 'through the eyes of St. Stephen [the first king of Hungary in the 11 $1^{\text {th }}$ century]' [Orban 2020]. In Poland, in November 2019, Jarosław Kaczyński, the leader of the governing Law and Justice (PiS) party, likewise declared the Church to be the only common referent object in contemporary Poland when it came to values, while his party declared their goal and mission as being to 're-Christianize' Europe. Evangelicals and public intellectuals in both Europe and the US also began producing books praising the end of the "postwar 
consensus' after the Second World War, and endorsing the rise of nationalism, faith, and an end to 'universalizing' principles of law, gender, migrants, and human rights [Reno 2019; Hazony 2018]. To explain this kind of outcome requires acknowledging the contribution made by dissidents other than Ilyenkov after 1979.

The dissidents who first provided the intellectual narrative that became dominant during the last decade of Soviet socialism in Europe explicitly rejected what they increasingly saw as a utopian project to change human nature itself. Their dominant articulated desire was to create 'open societies' capable of 'normal political life', in a manner which they themselves idealized, already existed in Western Europe and the US. In Germany, Jürgen Habermas welcomed 'the lack of ideas that are either innovative or oriented towards the future' after 1989, whilst Adam Michnik in Poland also longed for 'an anti-utopian revolution, because utopias lead to the guillotine and the gulag' [Krastev, Holmes 2020, p. 24]. In the 1990s, however, the natural corollary of Michnik's own belief in 'normality' - that Poland needed to move forward without vengeance or vendettas rooted in the past - also incidentally led him to increasingly enter the crosshairs of the Polish political right, who, by contrast, longed to complete an 'authentic' revolution by purging from public life past employees of the socialist system. In general, the postmodern revolution that East European intellectuals saw themselves as enacting in 1989 led eventually to public disillusionment, and to the rise of new, more nationalist and populist ideologies, which offered an alternate mobilizational narrative for explaining the course of recent history. These populist narratives were themselves devoid of any rich semiotic content, resting instead mostly on thinly grounded myths of primordial nationalism, religion, race, and identity politics. They were however the natural stepchildren of the anti-utopian turn that had occurred in 1989, with the legal norm hegemony imposed by the EU now even being equated, in many of these new narratives, with the humiliations of the earlier Soviet 'totalitarian' experience. The roots of the intellectually impoverished illiberalism currently shaping Central Europe therefore unquestionably lie, as Kravtsev and Holmes have recently argued, in 'the intellectual poverty of the 1989 revolutions, undertaken in the name of normality' [Krastev, Holmes 2020, p. 70]. Being themselves incapable of creating any form of coherent resolution, founded in subjective idealism, and perpetuated instead by ongoing social division, these movements dramatically highlight the inability of history to end, and the need to return instead to a politics founded in debate around the content of a universal ideal.

That 'memory politics' cannot fill the gap created by the abandonment of political meta-narratives is now obvious, in a world where memory itself is now increasingly weaponized and used purely as political ammunition in the hands of authoritarians. It therefore remains difficult to see another way of collectively moving forward other than to return to a political form of debate that openly discusses the form and nature of a universal ideal. Such an ideal is defined not by nationalism or by race, but by the distinct nature of humanity itself compared to all other animals, a unique being, whose uniqueness consists precisely in the fact that:

the 'ideal' exists only in man. Outside him and beyond him there can be nothing 'ideal'. Man, however, is to be understood not as one individual with a brain [or as one nation-AM], but as a real ensemble of real people collectively realizing their specific human life-activity, 
as the 'ensemble of all social relations' arising between people around one common task, around the process of the social production of their life (Ilyenkov "Dialectics of the Ideal" in [Levant, Oittinen 2014, p. 77]).

To return to a politics that engages with the 'ensemble of all social relations' and to debate around the ideal form of 'social production' requires a return to the politics of Lenin. We are not obliged by this course to return to the paths Lenin himself personally followed or advocated, or to agree with the often purely contingent solutions that he reached in his own day as either viable or appropriate recipes for our own era. But to escape the dead end of postmodernism, and its current bastard stepchild, the era of 'posttruth' politics, requires a collective return to engaging with the dialectics of the ideal.

\section{References}

Brown A. (ed.) (2004) The Demise of Marxism-Leninism in Russia, Oxford: Palgrave Macmillan.

Forest B., Johnson J. (2002) Unravelling the Threads of History: Soviet-Era Monuments and PostSoviet National Identity in Moscow. Annals of the Association of American Geographers, vol. 92 , no 3, pp. 524-547.

Gamboni D. (2013) The Destruction of Art: Iconoclasm and Vandalism since the French Revolution, London: Reaktion Books Ltd.

Gleason G. (1990) Lenin, Gorbachev, and 'National-Statehood': Can Leninism Countenance the New Soviet Federal Order? Studies in Soviet Thought, vol. 40, no 1/3, pp. 137-158.

Hazony Y. (2018) The Virtue of Nationalism, New York: Basic Books.

Ilyenkov E.V. (1982) Leninist Dialectics and the Metaphysics of Positivism, London: New Park Publications.

Krastev I., Holmes S. (2020) The Light that Failed. A Reckoning, Milton Keynes: Penguin Books.

Lenin V.I. (1965) Our Revolution. Lenin V.I. Collected Works, vol. 33, Moscow: Progress Publishers.

Lenin V.I. (1972) Philosophical Notebooks. Lenin V.I. Collected Works, vol. 38, Moscow: Progress Publishers.

Lenin V.I. (1999) Neizvestnye dokumenty 1891-1922 [Unknown Documents 1891-1922], Moscow: ROSSPEN.

Levant A., Oittinen V. (eds.) (2014) Dialectics of the Ideal. Evald Ilyenkov and Creative Soviet Marxism, Chicago: Haymarket Books.

Marx K. (1873 (1953)) Capital, vol. 1, Moscow: Foreign Languages Publishing House.

Masis J. (2017) A Century after the Revolution, Russians Build Monuments to the Czars. Global Post, November 7, 2017. Available at: https://www.pri.org/stories/2017-11-07/centuryafter-revolution-russians-build-monuments-czars, accessed 22.06.2020.

Miller C. (2016) The Struggle to Save the Soviet Economy. Mikhail Gorbachev and the Collapse of the USSR, Chapel Hill: University of North Carolina Press.

Nikulin D. (2015) Memory: A History, Oxford: OUP.

Orban V. (2020) Prime Minister Viktor Orban's Commemoration Speech. About Hungary, June 6, 2020. Available at: http://abouthungary.hu/speeches-and-remarks/primeminister-viktororbans-commemoration-speech-trianon/, accessed 22.06.2020.

Peterson D.J. (2019) Troubled Lands. The Legacy of Soviet Environmental Destruction, London: Routledge

Popov G. (2010) A Flaw in the Design. Lenin's Dead End, Middlesex: OS Enterprises. 
Popper K. (1945 (2011)) The Open Society and Its Enemies, London: Routledge.

Raining Lenins (2020). Available at: http://dighist.fas.harvard.edu/projects/eurasia/exhibits/ show/raining lenins/item/312, accessed 22.06.2020.

Reno R.R. (2020) The Return of the Strong Gods: Nationalism, Populism, and the Future of the West, Washington: Gateway Editions.

Shane S. (1995) Dismantling Utopia: How Information ended the Soviet Union, Chicago: I.R. Dee.

Stalin J. (1924) The Foundations of Leninism. Marxists Internet Archive. Available at: https://www.marxists.org/reference/archive/stalin/works/1924/foundations-leninism/ch09.htm, accessed 22.06.2020.

The Programme of the Communist Party of the Soviet Union (1961), Moscow: Foreign Languages Publishing House.

Titov A. (2009) The 1961 Party Programme and the Fate of Khrushchev's Reforms. State and Society under Nikita Khrushchev (eds. Ilic M., Smith J.), London: Routledge, pp. 8-25.

Walker R. (1993) Six Years that Shook the World. Perestroika: the Impossible Project, Manchester: Manchester University Press.

Yurchak A. (2015) Bodies of Lenin: The Hidden Science of Communist Sovereignty. Representations, vol. 129, no 1, pp. 116-157.

Yurchak A. (2017) The Canon and the Mushroom: Lenin, Sacredness and the Soviet Collapse. HAU: Journal of Ethnographic Theory, vol. 7, no 2, pp. 165-198.

Zarkar R. (2015) Goodbye Lenin, Hello Timur: The Evolution of National Monuments in Uzbekistan's Capital City. Ajam Media Collective, July 7, 2015. Available at: https://ajammc.com/2015/07/07/goodbye-lenin-hello-timur/, accessed 22.06.2020.

\title{
Наследие Ленина 150 лет спустя
}

\author{
А. МАРШАЛЛ*
}

\begin{abstract}
*Алекс Маршалл - доктор исторических наук, лектор, Университет Глазго. Адрес: History, Room 406, 1 University Gardens, Glasgow G12 8QQ, United Kingdom. E-mail: Alexander.Marshall@glasgow.ac.uk
\end{abstract}

Цитирование: Marshall A. (2020) The Shadow and the Substance of Lenin after 150 Years. Mir Rossii, vol. 29, no 4, pp. 134-149. DOI: 10.17323/1811-038X-2020-29-4-134-149

В 150-летнюю годовщину рождения В.И. Ленина в академическом сообществе поднимается вопрос об оставленном историческом наследии основателя большевистской партии. Проводя грань между Лениным-человеком и почти 70-летним культом почитания его памяти, с одной стороны, и его методом и образом мышления, с другой, в статье предпринимается попытка оценить значение фигуры В.И. Ленина для сегодняшней Европы. Основу данного исследования составляет анализ основных идей В.И. Ленина в интерпретации Э.В. Ильенкова.

В каком-то смысле нынешняя европейская политика по-прежнему остается побочным продуктом отрицания ленинизма после 1989 г., а именно ленинизма, который с 1924 г. эволюционировал в социологическую теорию, предполагающую набор практических мер для осуществления ускоренной модернизации в отстающих 
обществах. Отрицание ленинизма как альтернативной формы модерна в странах Центрально-Восточной Европы привело к его замещению постмодернистской политикой памяти, которая, хоть и ускорила развитие конкурентной политической культуры, все же оказалась зацикленной преимущественно на вопросах культурных и религиозных различий, нередко перерождаясь в радикальный этнический национализм.

Об этой опасности предупреждал советской философ Э.В. Ильенков, который на основе переосмысления диалектики идеального, впервые изученной К. Марксом и В.И. Лениным, попытался противостоять подъему неопозитивистского мышления 1960-1970-х гг. Выявив скрытую угрозу в механистическом материализме, он не менее открыто противостоял субъективному «социализму с человеческим лицом» и прочим идеалистическим течениям, развившимся как отклик на неопозитивистскую риторику советской социальной жизни. И в этом он, безусловно, разделял позицию В.И. Ленина, считавшего, что истинное определение идеального возможно лишь в конкретный исторический момент и лишь в результате сплоченных коллективных усилий общества, а не через принятие какой-либо из вышеобозначенных крайностей. Таким образом, Э.В. Ильенкова в определенном смысле можно считать современным проводником ленинских идей.

Ключевые слова: В.И. Ленин, Э.В. Ильенков, ленинизм, постмодернизм, диалектика, материализм, философия, Европа

\section{Литература}

Ленин В.И. (1999) Неизвестные документы 1891-1922. М.: РОССПЭН.

Brown A. (ed.) (2004) The Demise of Marxism-Leninism in Russia, Oxford: Palgrave Macmillan. Forest B., Johnson J. (2002) Unravelling the Threads of History: Soviet-Era Monuments and Post-Soviet National Identity in Moscow // Annals of the Association of American Geographers, vol. 92, no 3, pp. 524-547.

Gamboni D. (2013) The Destruction of Art: Iconoclasm and Vandalism since the French Revolution, London: Reaktion Books Ltd.

Gleason G. (1990) Lenin, Gorbachev, and 'National-Statehood': Can Leninism Countenance the New Soviet Federal Order? // Studies in Soviet Thought, vol. 40, no 1/3, pp. 137-158.

Hazony Y. (2018) The Virtue of Nationalism, New York: Basic Books.

Ilyenkov E.V. (1982) Leninist Dialectics and the Metaphysics of Positivism, London: New Park Publications.

Krastev I., Holmes S. (2020) The Light that Failed. A Reckoning, Milton Keynes: Penguin Books. Lenin V.I. (1965) Our Revolution // Lenin V.I. Collected Works, vol. 33, Moscow: Progress Publishers.

Lenin V.I. (1972) Philosophical Notebooks // Lenin V.I. Collected Works, vol. 38, Moscow: Progress Publishers.

Levant A., Oittinen V. (eds.) (2014) Dialectics of the Ideal. Evald Ilyenkov and Creative Soviet Marxism, Chicago: Haymarket Books.

Marx K. (1873 (1953)) Capital, vol. 1, Moscow: Foreign Languages Publishing House.

Masis J. (2017) A Century after the Revolution, Russians Build Monuments to the Czars // Global Post, November 7, 2017 // https://www.pri.org/stories/2017-11-07/ century-after-revolution-russians-build-monuments-czars 
Miller C. (2016) The Struggle to Save the Soviet Economy. Mikhail Gorbachev and the Collapse of the USSR, Chapel Hill: University of North Carolina Press.

Nikulin D. (2015) Memory: A History, Oxford: OUP.

Orban V. (2020) Prime Minister Viktor Orban's Commemoration Speech // About Hungary, June 6, 2020 // http://abouthungary.hu/speeches-and-remarks/primeminister-viktor-orbanscommemoration-speech-trianon/

Peterson D.J. (2019) Troubled Lands. The Legacy of Soviet Environmental Destruction, London: Routledge

Popov G. (2010) A Flaw in the Design. Lenin's Dead End, Middlesex: OS Enterprises.

Popper K. (1945 (2011)) The Open Society and Its Enemies, London: Routledge.

Raining Lenins (2020) // http://dighist.fas.harvard.edu/projects/eurasia/exhibits/show/raining lenins/item/312

Reno R.R. (2020) The Return of the Strong Gods: Nationalism, Populism, and the Future of the West, Washington: Gateway Editions.

Shane S. (1995) Dismantling Utopia: How Information ended the Soviet Union, Chicago: I.R. Dee.

Stalin J. (1924) The Foundations of Leninism // Marxists Internet Archive // https://www.marxists.org/reference/archive/stalin/works/1924/foundations-leninism/ch09.htm

The Programme of the Communist Party of the Soviet Union (1961), Moscow: Foreign Languages Publishing House.

Titov A. (2009) The 1961 Party Programme and the Fate of Khrushchev's Reforms // State and Society under Nikita Khrushchev (eds. Ilic M., Smith J.), London: Routledge, pp. 8-25.

Walker R. (1993) Six Years that Shook the World. Perestroika: the Impossible Project, Manchester: Manchester University Press.

Yurchak A. (2015) Bodies of Lenin: The Hidden Science of Communist Sovereignty // Representations, vol. 129, no 1, pp. 116-157.

Yurchak A. (2017) The Canon and the Mushroom: Lenin, Sacredness and the Soviet Collapse // HAU: Journal of Ethnographic Theory, vol. 7, no 2, pp. 165-198.

Zarkar R. (2015) Goodbye Lenin, Hello Timur: The Evolution of National Monuments in Uzbekistan's Capital City // Ajam Media Collective, July 7, 2015 // https://ajammc.com/2015/07/07/goodbye-lenin-hello-timur/ 